Seminar Nasional Penelitian dan Pengabdian kepada Masyarakat

Universitas Sang Bumi Ruwa Jurai Tahun 2020

\title{
WORKSHOP SOSIALISASI KOMUNIKASI S.B.A.R PADA PERAWAT
}

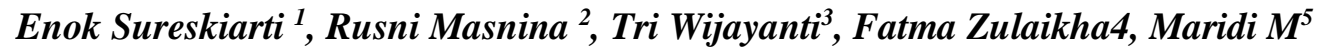 \\ 1,2,3,4,5 Dosen Prodi Ilmu keperawatan dan Ners Fakultas Ilmu Kesehatan dan Farmasi \\ es202@umkt.ac.id
}

\begin{abstract}
Abstrak
Komunikasi yang tidak efektif akan menimbulkan risiko kesalahan dalam pemberian asuhan keperawatan. Sebagai contoh kesalahan dalam pemberian obat ke pasien, kesalahan melakukan prosedur tindakan perawatan. Mencegah terjadinya risiko kesalahan pemberian asuhan keperawatan maka perawat harus melaksanakan sasaran keselamatan pasien : komunikasi efektif di Instalasi Rawat Inap. Komunikasi efektif dapat dilakukan antar teman sejawat (dokter dengan dokter/ perawat dengan perawat) dan antar profesi (perawat dengan dokter). Kualitas suatu rumah sakit sebagai institusi yang menghasilkan produk teknologi jasa kesehatan sudah tentu tergantung juga pada kualitas pelayanan medis dan pelayanan keperawatan yang diberikan kepada pasien, komunikasi efektif dalam praktik keperawatan profesional merupakan unsur utama bagi perawat dalam melaksanakan asuhan keperawatan dalam mencapai hasil yang optimal. Kegiatan keperawatan yang memerlukan komunikasi efektif adalah saat serah terima tugas (handover) dan komunikasi lewat telepon, Pengabdian Masyarakat ini adalah suatu bentuk Workshop Komunikasi SBAR ( Situation, Bacground, Assesment, Recomendation) pada perawat Di ruang Melati RSUD Abdul Wahab Syahranie yang dilaksanakan pada tanggal 12-13 Febuari 2019 yang diikuti oleh 31 perawat.
\end{abstract}

Kata kunci: Komunikasi. SBAR, Perawat

\begin{abstract}
Ineffective communication will pose a risk of error in the provision of nursing care. For example, errors in drug administration to patients, errors in the procedure of treatment. Preventing the risk of errors in nursing care nurses must carry out patient safety goals: effective communication at the Inpatient Installation. Effective communication can be done between peers (doctors with doctors / nurses and nurses) and between professions (nurses and doctors). The quality of a hospital as an institution that produces health service technology products certainly depends also on the quality of medical services and nursing services provided to patients, effective communication in professional nursing practice is a key element for nurses in implementing nursing care in achieving optimal results. Nursing activities that require effective communication are when handover and telephone communication, Community Service is a form of SBAR Communication Workshop for nurses In the Melati room Abdul Wahab Syahranie Hospital which was held on 12-13 February 2019, which was attended by 31 nurse
\end{abstract}

Keywords : Comunication, S.B.A.R, and Nurse

\section{PENDAHULUAN}

Dalam pelaksanaan operan, perawat berkomunikasi membahas hal-hal yang berkaitan dengan pasien yang menjadi tanggung jawabnya dengan menggunakan dokumentasi sebagai sumber informasi. Hal-hal yang dibicarakan mengenai kondisi pasien terkini, pengobatan dan perencanaan keperawatan, alokasi pasien, dan prioritas pelayanan lainnya (Nursalam, 2011). Kegiatan pendokumentasian keperawatan yang terjadi saat ini masih banyak ditemui berbagai hambatan yang mengakibatkan asuhan keperawatan yang tidak optimal. Hal ini karena banyaknya faktor yang mempengaruhi seperti beban kerja, pengetahuan, waktu, keterampilan perawat, pengalaman kerja perawat, pendidikan, motivasi, tenaga, sarana, dan faktor sosial (Purba, 2012).

Sistem dokumentasi yang ideal harus memberikan informasi pasien yang komprehensif, mampu menampilkan data tentang keadaan pasien dari tingkat kesakitan, jenis, kualitas dan kuantitas dari 
layanan yang telah diberikan perawat dalam memenuhi kebutuhan pasien, memfasilitasi bantuan pembayaran dari pemerintah dan perusahaan asuransi pembayar, serta berfungsi sebagai dokumen yang legal (Sugiarto, 2012). Komunikasi efektif merupakan unsur utama dari sasaran keselamatan pasien karena komunikasi adalah penyebab pertama masalah keselamatan pasien (patient safety). Komunikasi yang efektif yang tepat waktu, akurat, lengkap, jelas, dan dipahami oleh penerima mengurangi kesalahan dan meningkatkan keselamatan pasien. Maka dalam komunikasi efektif harus dibangun aspek kejelasan, ketepatan, sesuai dengan konteks baik bahasa dan informasi, alur yang sistematis, dan budaya. Komunikasi yang tidak efektif akan menimbulkan risiko kesalahan dalam pemberian asuhan keperawatan (Alvarado, Dkk, 2006). Kerangka komunikasi efektif terkini yang digunakan di rumah sakit adalah komunikasi SBAR, WHO mewajibkan kepada rumah sakit untuk menggunakan suatu standar yang strategis yaitu dengan menggunakan metode komunikasi SBAR. Komunikasi SBAR merupakan komunikasi yang terdiri dari 4 komponen yaitu S (Situation) merupakan suatu gambaran yang terjadi pada saat itu. B (Background) merupakan sesuatu yang melatar belakangi situasi yang terjadi. A (Assessment) merupakan suatu pengkajian terhadap suatu masalah. R (Recommendation) merupakan suatu tindakan dimana meminta saran untuk tindakan yang benar yang seharusnya dilakukan untuk masalah tersebut (Cahyono, 2008).

Komunikasi SBAR dalam dunia kesehatan dikembangkan oleh pakar patient safety dari Californiauntuk membantu komunikasi antaradokter dan perawat. Komunikasi SBAR di desain untuk komunikasi dalam situasi beresiko tinggi antara perawat dan dokter untuk mengatasi masalah pasien (cahyono, 2008). Hasil studi literatur yang dikembangkan oleh Velji (2010) mengenai efektifitas dokumentasi SBAR dalam pengaturan rehabilitasi didapatkan bahwa penggunaan dokumentasi SBAR memiliki potensi untuk meningkatkan komunikasi tim interprofesional dalam konteks rehabilitasi dan kontribusi berharga dalam praktek keselamatan pasien. Penelitian Supinganto, Mulianingsih \& Suharmanto (2015) di rumah sakit RSUD kota Mataram menunjukkan bahwa pada komponen komunikasi situation (S) sebagian besar dalam kategori efektif sebanyak 82,0\%, pada komponen komunikasi background (B) sebagian besar dalam kategori tidak efektif sebanyak 78,0\%, pada komponen komunikasi assessment (A) sebagian besar dalam kategori tidak efektif sebanyak 64,0\% dan pada kategori komponen komunikasi recommendation (R) sebagian besar dalam kategori tidak efektif sebanyak 64,0\%. Secara umum, sebagian besar komunikasi perawat dalam kategori efektif. Komunikasi dapat menjadi sulit ketika orang yang berkomunikasi memiliki tingkat pengetahuan yang berbeda, pesan akan menjadi tidak jelas jika kata-kata dan ungkapan yang digunakan tidak dikenal oleh pendengar. Dari uraian diatas kami mengadakan pengabdian masyarakat terkait penggunaaan metode SBAR dalam komunikasi perawat dan tenaga kesehatan guna membantu pasien dalam memecahkan masalah kesehatannya. Kegiatan ini diadakan di Ruang melati RSUD AWS Samarinda ruang Melati pada tanggal 12-13 Febuari 2019.

\section{Strategi}

\section{METODE}

Melakukan Suryei awal sebelum melaksanakan workshop dilakukan dahulu survei awal terkait pengetahuan tenaga kesehatan di Ruang Melati Rsud AWS Samarinda apakah sudah menggunakan Komunikasi Efektif menggunakan S.B.A.R atau belum. Dari observasi ke pada 12 perawat ruang Melati ternyata belum menggunakan komunikasi Efektif S.B.A.R dengan optimal oleh karena itu saya dan Tim ingin Melaksanakan Pengabdian Masyarakat berupa Workshop terkait komunikasi Efektif menggunakan tehnik SBAR untuk tenaga kesehatan pada umumnya dan perawat pada Khususnya.

2. Kegiatan

Kegiatan dilaksanakan di Ruang Melati yaitu di ruang Terapi Bermain yang di miliki ruang Melati yang Target workshop ini adalah seluruh perawat yang berada di ruang melati yang berjumlah 31 408 
perawat tetapi karenaada 5 perawat yang berhalanganun untuk mengikuti dikarenakan cuti melahirkan, studi lanjut, ijin keperluan keluarga dan ijin Sakit, maka di ikuti oleh 26 Perawat yang berdinas 26 perawat ini di bagi 2 kelompok masing masing kelompok 13 perawat kegiatan di laksanakan di Melati dan Ditambah Struktural Rumah sakit bagian Keperawatan. Pelaksanaannya di lakukan selama 2 hari. Untuk Kegiatan Hari pertama yaitu pada tanggal 12 Febuari 2019 dilaksanakan di ruangan berupa materi dan Roleplay Komunikasi Efektif S.B.A.R dengan disiplin ilmu (Dokter, perawat, ahli gizi dll) di mulai jam 08.00-16.00 Wita. Kegiatan Hari Kedua yaitu tanggal 13 Febuari 2019 di laksanakan di Ruang Rembulan denganagenda Evaluasi terhadap workshop yang sudah di berikan sebelumnya.

\section{HASIL DAN PEMBAHASAN}

1. Pelaksanaan Pengabdian :

a. Mendata nama-nama perawat yang berdinas di Ruang Melati RSUD AWS Samarinda 8 Febuari 2019.

b. Penjelasan dan perijinan maksut disosialisasikan Komunikasi Efektif SBAR 8 Febuari 2019 ,

c. Perijinan tempat, lokasi pengabdian masyarakat 8 Febuari 2019 .

d. Memberikan materi terkait komunikasi Sbar dan melakukan implementasi pada 12 Febuari 2019 di ruang Melati .

e. Melakukan Evaluasi terkait implementasi komunikasi Efektif sbar di ruang rembulan yang di ikuti perawat ruang melati dan structural rumah sakit rsud aws samarinda pada tanggal 13 Febuari 2019.

2. Dokumentasi Kegiatan

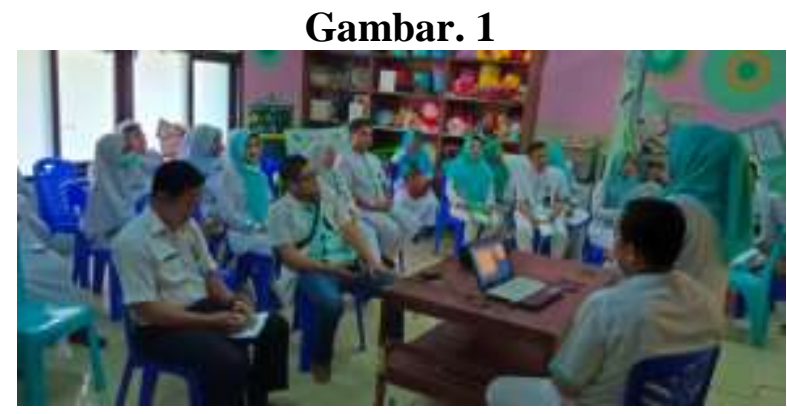

Kegiatan saat implementasi komunikasi Efektif dengan metode SBAR.

Gambar. 2

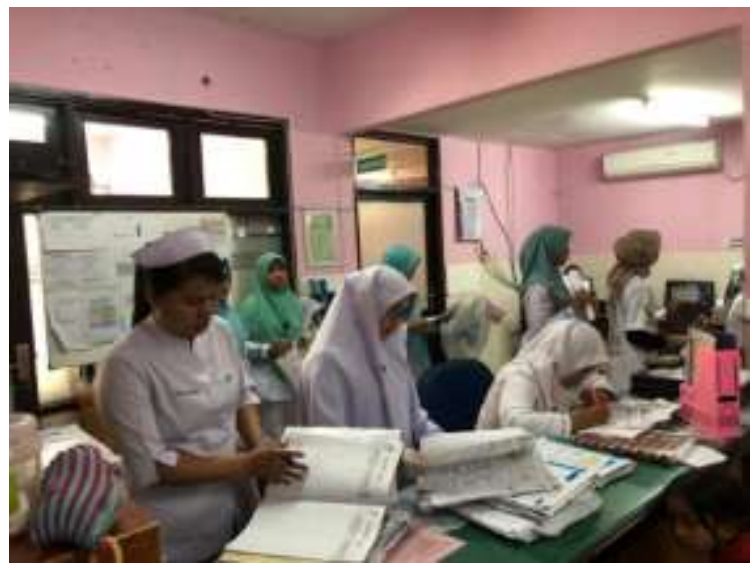


Melakukan roleplay komunikasi Efektif dengan SBAR

Gambar 3.

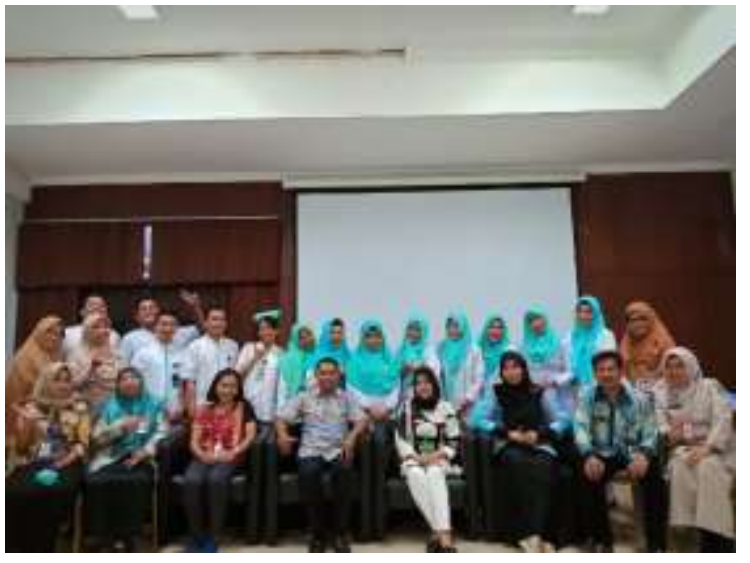

Selesai proses evaluasi pengetahuan komunikasi Efektif SBAR hari kedua 13 Febuari 2019

\section{Gambar 4}

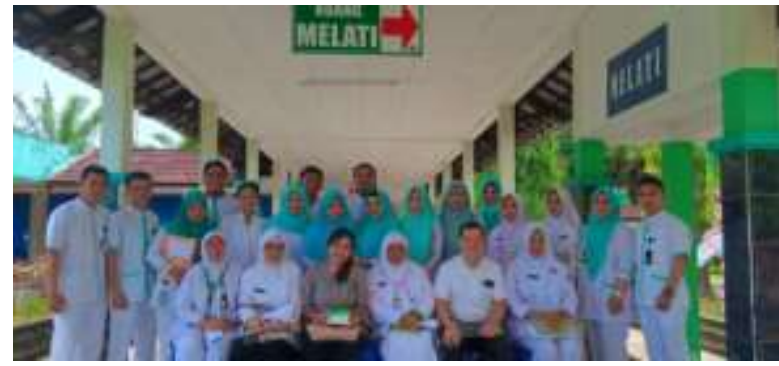

Selesai penyampaian materi komunikasi efektif dengan metode SBAR hari pertama 12 febuari 2019

3. Hasil Pengabdian dan Luaran Yang diperoleh :

Perawat Ruang Melati sejumlah 26 Perawat telah memiliki pengetahuan terkait Komuikasi efektif dengan menggunakan metode SBAR dengan benar dan Tepat dan bisa mengimplementasikan penggunaannya di saat berdinas sehari-hari. Berikut table dan diagram hasil evaluasi terkait Pengetahuan Komunikasi Efektif menggunakan Metode SBAR

Tabel 4.1 Pengetahuan Komunikasi Efektif mnggunakan Metode SBAR

KELOMPOK 1 KELOMPOK 2

\begin{tabular}{cccccc}
\hline No & pre sosialisasi & post sosialisasi & No & pre sosialisasi & post sosialisasi \\
\hline $\mathbf{1}$ & 60 & 68 & 14 & 60 & 80 \\
\hline $\mathbf{2}$ & 58 & 70 & 15 & 54 & 84 \\
\hline $\mathbf{3}$ & 56 & 73 & 16 & 52 & 78 \\
\hline $\mathbf{4}$ & 56 & 76 & 17 & 54 & 86 \\
\hline $\mathbf{5}$ & 54 & 78 & 18 & 54 & 94 \\
\hline $\mathbf{6}$ & 38 & 80 & 19 & 52 & 90 \\
\hline $\mathbf{8}$ & 66 & 78.0 & 21 & 62 & 78 \\
\hline $\mathbf{9}$ & 56 & 78.0 & 22 & 74 & 80 \\
\hline $\mathbf{1 0}$ & 58 & 80 & 23 & 54 & 90 \\
\hline $\mathbf{1 1}$ & 58 & 90 & 24 & 74 & 78 \\
\hline $\mathbf{1 2}$ & 76 & 94 & 25 & 62 & 80 \\
\hline $\mathbf{1 3}$ & 72 & 90 & 26 & 78 & \\
\hline
\end{tabular}




\section{Diagram 4.1 Kelompok 1 Pengetahuan Komunikasi Efektif mnggunakan Metode SBAR}

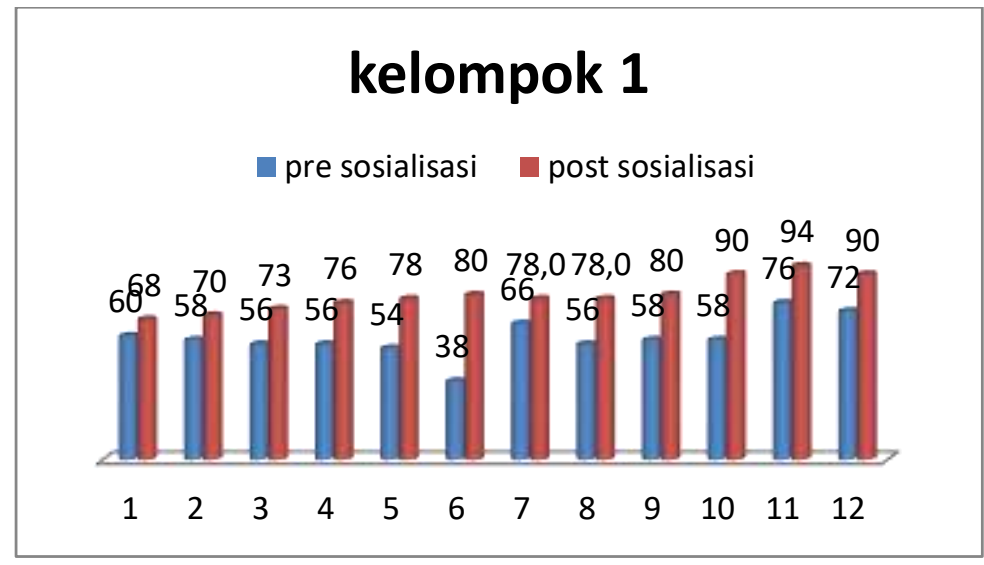

\section{Diagram 4.2 Kelompok 2 Pengetahuan Komunikasi Efektif mnggunakan Metode SBAR}

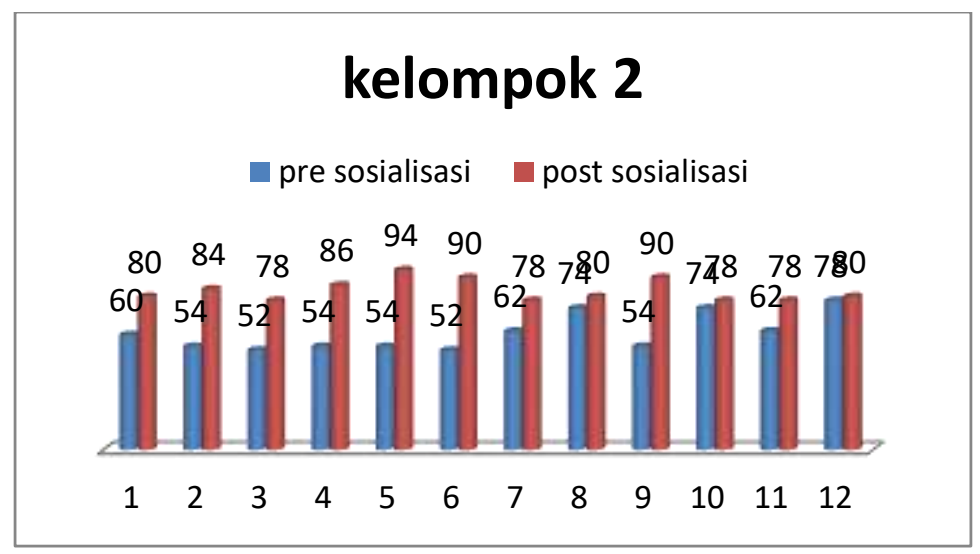

\section{KESIMPULAN DAN SARAN}

Berdasarkan hasil pengabdian Masyarakat seperti yang telah diuraikan sebelumnya, maka dapat ditarik beberapa kesimpulan sebagai berikut:

1. Kesimpulan

Pengetahuan Perawat Ruang Melati sebelumnya belum mengetahui terkait komunikasi Efektif SBAR dan bagaimana cara melakukannya setelah dilakukan workshop sosialisasi komunikasi efektif dengan Metode SBAR menjadi mengetahui dan memahami bagimana cara mengunakan komunikasi tersebut sehari-hari saat dinas.

2. Saran

Perlu dilakukannya lagi pelatihan-pelatihan kepada perawat terkait ilmu- ilmu manajemen keperawatan dan kesehatan supaya perawat dapat meningkatkan pengetahuannya sehingga dapat optimal dalam memeberikan pelayanan keperawatan.

\section{UCAPAN TERIMA KASIH}

Tim penulis mengucapkan terima kasih kepada Allah Subhanahu watta Alla dan penulis juga mengucapkan terimakasih kepada Lembaga Pengabdian Pada Masyarakat (LPPM) Universitas Muhammadiyah Kalimantan Timur yang telah mendanai kegiatan pengabdian ini sehingga terlaksana dengan baik.Penulis juga mengucapkan Terimakasih yang sebesar besarnya kepada 
Universitas Sang Bumi Ruwa Jurai Lampung yang telah mengijinkan Penulis melakukan publikasi di Event acara Seminar Nasional yang diadakannya tahun 2020 ini.

\section{DAFTAR PUSTAKA}

Nursalam. 2011. Manajemen Keperawatan Aplikasi dalam Praktik Keperawatan Profesional. Jakarta : Salemba Medika

Rostandi Purba, Juli. Achmad fathi. 2012. Jurnal Gaya Kepemimpinan dan Manajemen Koflik Kepala Ruangan di Instalasi Rindu A RSUP H. Adam Malik Medan

Sugiharto, A. S, Dkk. 2012. Manajemen Keperawatan Aplikasi MPKP di Rumah Sakit. Jakarta: EGC

Alvarado, K., Lee, R., Christoffersen, E., Fram, N., Boblin, S., Poole, N., et al. (2006). Transfer of acountability: Transforming shift handover to enhance patient safety. Health Care Quarterly. Special Issue (9), 75 - 79.

Cahyono. (2008). Membangun budaya keselamatan pasien dalam praktek kedokteran. Yogyakarta: Kanisius

Calalang, V. H., \& Javier. (2010). Standards of effective communication. Dari http://www.bellaonline.com/articles/art46170.asp di akses 18 April 2014

Clancy. M.C., \& Collins, B. A. (2005). Focus on patient safety: Patient safety in nursing practice. Journal of Nursing Care Quality. 20 (3), 193 - 197.

Clark, E., Squire, S., Heyme, A., Mickle, M. E., Petrie, E. (2009). The PACT project: Improving communication at handover. Journal of Advance Management, 190(11), 125 - 127.

Howarth, T., \& Hyde, G. (2008). Developing and implementing new clinical communication practices: changing the hursing handover. Dari http://www.changechampions.com.au/resource/Gerard_Hyde.pdf. di akses 18 April 2014.

Keliat,Budi Anna. 2009. Pedoman Pelayanan Keperawatan Profesional, Jakarta : EGC

Nursalam. 2015. Manajemen Keperawatan, Aplikasi dan Praktik Keperawatan Profesional, Edisi 5. Jakarta: Salemba Medika) 